\title{
ВИРАЗНІСТЬ ГАЗЕТНОГО ЗАГОЛОВКА
}

\author{
Марія Ріпей \\ Львівський національний університет імені Івана Франка, \\ вул. Генерала Чупринки, 49, 79044, Львів, Україна, \\ e-mail: maria-kr@ukr.net \\ https://orcid.org/0000-0001-6040-3539
}

Простежено особливості подання газетного заголовка з погляду виразності. Проаналізовано випадки неправильного розподілу газетного заголовка на рядки, зосереджено увагу на смисловому значенні кожного рядка заголовка. Розглянуто приклади подання у газетних заголовках цифр. Акцентовано, що форма заголовка як головного елемента газетного матеріалу не має шкодити його змісту, а повинна робити його більш виразним і привабливим. Від цього значною мірою залежить вплив на читачів як заголовка, так і публікації в цілому.

Ключові слова: газетний заголовок, рядок заголовка, оформлення, смислове значення.

Загальна проблема та ї̈ науково-практичне значення. Велика роль заголовка у сприйнятті, розумінні та інтерпретації тексту. Його називають зовнішнім індикатором тексту, ядром ідеї твору [8: 59-60]. Заголовок виконує домінантну функцію тексту, метою якої є сформувати чітке уявлення про зміст повідомлення та звернути на нього увагу. В газетному заголовку зосереджені найважливіші пункти повідомлення в легкій і стиснутій формі [10: 72]. Водночас заголовок «налаштовує на певний спосіб осмислення порушеної проблеми, задає емоційно-оцінну тональність її потрактування» [2: 153].

На думку дослідників [4: 66], заголовок дає змогу читачеві зробити вибір, що читати; спонукає прочитати той чи інший текст; дає можливість структурувати сторінку газети; впливає на імідж видання.

Заголовок у газеті ми читаємо найперше, дізнаючись про зміст надрукованих матеріалів. Його написання повинно відповідати мовним, поліграфічним та видавничим нормам. 3 огляду на це «працювати над заголовком журналіст повинен з особливою вимогливістю до себе» [9: 34]. Водночас заголовок потребує особливої уваги літературного редактора (коректора). Науковці зазначають [1: 10], що у тексті, набраному великим шрифтом, легко пропустити помилку. Під час читання такого тексту набагато важче зосередити увагу, ніж під час читання звичайного набору. Редактор (коректор) повинен зважати на цю особливість і бути особливо уважним під час вичитування заголовків, підзаголовків і різних шрифтових виділень.

(C) Ріпей М., 2019

Наукове керівництво, редагування і рекомендація до друку - доц. Капелюшний А. О. 
Аналіз досліджень і публікацій. Про оформлення газетних заголовків пишуть у своїх працях В. Іванов [6]; А. Капелюшний; Т. Крайнікова; А. Кулаков [9]; Е. Лазарева [10]; А. Мільчин [13]; 3. Партико; М. Феллер, І. Квітко, М. Шевченко [14] та ін.

Ставили за мету простежити особливості подання газетного заголовка з погляду виразності.

Аналізований фактаж дібрано із газети «Волинські новини» (https://www. volynnews.com $)^{1}$. Період дослідження - від 1 вересня 2018 року до 1 лютого 2019 року.

Виклад матеріалу. У структурі газетного тексту заголовок відіграє важливу роль. Гарний заголовок надає матеріалу «силу і блиск» [3: 15]. Як зазначає В. Іванов, «гарний газетний заголовок має впливати на читача, і тому в його основі завжди лежать відповідність змістові, ясність, точність, яскравість, виразність» [6: 109-110].

1. Емоційний вплив публікації значною мірою залежить від форми газетного заголовка. Вона особливо важлива тоді, коли заголовок складається з декількох рядків. Під час поділу заголовка на рядки треба звертати увагу на те, щоб кожен рядок мав свій акцент, свій сенс [5: 118].

На сторінках «Волинських новин» трапляються випадки, коли кожний рядок заголовка не має смислового значення. Особливу увагу варто звернути на заголовки, у яких розриваються тісно пов'язані між собою слова, що значно ускладнює їх сприйняття. Зокрема, «солодка ягода», «відомий спортсмен», «дім молитви», «робочі суботи», «нові технології», «українська церква». У разі правильного написання ці заголовки були б чіткіші й зрозуміліші. Наприклад:

\begin{tabular}{|c|c|}
\hline Неправильно & Правильно \\
\hline $\begin{array}{l}\text { Любитель солодкої } \\
\text { ягоди посіяв... гриби } \\
(17 \text { січня } 2019 \text { р.) }\end{array}$ & $\begin{array}{l}\text { Любитель солодкої ягоди } \\
\text { посіяв... гриби }\end{array}$ \\
\hline $\begin{array}{l}\text { На Волині в ДТП загинув відомий } \\
\text { спортсмен } \\
\text { (17 січня } 2019 \text { р.) }\end{array}$ & $\begin{array}{l}\text { На Волині в ДТП } \\
\text { загинув відомий спортсмен }\end{array}$ \\
\hline $\begin{array}{l}\text { За підпал дому } \\
\text { молитви - під суд } \\
(17 \text { січня } 2019 \text { р.) }\end{array}$ & $\begin{array}{l}\text { За підпал дому молитви - } \\
\text { під суд }\end{array}$ \\
\hline $\begin{array}{l}\text { У грудні-дві робочі } \\
\text { суботи } \\
\text { (1 листопада } 2018 \text { р.) }\end{array}$ & $\begin{array}{l}\text { У грудні- } \\
\text { дві робочі суботи }\end{array}$ \\
\hline $\begin{array}{l}\text { У майбутнє - з новими } \\
\text { технологіями } \\
\text { (29 листопада } 2018 \text { р.) }\end{array}$ & $\begin{array}{l}\text { У майбутнє - } \\
\text { з новими технологіями }\end{array}$ \\
\hline
\end{tabular}

\footnotetext{
${ }^{1}$ Інформаційне агентство «Волинські новини» - один зі «старожилів» електронного інформаційного простору Волині. Перші публікації видання почало транслювати з 22 травня 2008 року, а в загальному доступі для користувачів працює з 28 липня 2008 року. Це найперший електронний 3МІ Волині, який сформував власну багатотисячну аудиторію. Видання, згідно зі статистикою пошукових систем, читають не лише на Волині, а й по всій Україні та в інших країнах світу. Щодня ресурс відвідує понад 30 тисяч відвідувачів. У 2016 році видання отримало Міжнародний сертифікат «Leader of the branch 2016», медаль «Leader of the branch», орден «Decus oeconomicae», медаль «Bene merenti de professione», Міжнародний сертифікат «Employee of the year 2016» (https:// www.volynnews.com/about).
} 


\begin{tabular}{|c|c|}
\hline Неправильно & Правильно \\
\hline $\begin{array}{l}\text { Більшість прихожан - за украӥнську } \\
\text { иеркву, священик - проти } \\
(24 \text { січня } 2019 \text { р.) }\end{array}$ & $\begin{array}{l}\text { Більшість прихожан - за украӥнську иеркву, } \\
\text { священик - проти }\end{array}$ \\
\hline
\end{tabular}

Варто звернути увагу на заголовки

\begin{tabular}{|c|c|c|}
\hline $\begin{array}{l}\text { Для постави - соляні } \\
\text { мішечки, для очей - } \\
\text { тренажер Базарного } \\
\text { (22 листопада } 2018 \text { р.), }\end{array}$ & $\begin{array}{l}\text { Як гол легендарного } \\
\text { динамівця змінив жыття } \\
\text { шотландського індуса } \\
\text { (24 січня } 2019 \text { р.), }\end{array}$ & $\begin{array}{l}\text { Ігор Гузь: «Публічність } \\
\text { i відкритість- головні } \\
\text { приниипи роботи» } \\
\text { (20 грудня } 2018 \text { р.), }\end{array}$ \\
\hline
\end{tabular}

які умовно складаються 3 двох частин: головним словом (чи словами) першої частини (для кращого сприйняття ми їх виділили жирним шрифтом) є «для постави», «для очей»; «гол динамівця»; «публічність і відкритість»; а другої (для кращого сприйняття ми їх підкреслили) - «мішечки», «тренажер»; «життя індуса»; «принципи». Однак вони графічно поділені на три частини. Емоційний вплив цих заголовків був би сильніший за такого варіанта їх розміщення:

Для постави - соляні мімечки,

для очей - тренажер Базарного

Як гол легендарного динамівця

змінив життя шотландського індуса

Ігор Гузь: «Публічність і відкритість головні принципи роботи»

2. Рядок заголовка не може закінчуватись прийменником або сполучником [9: 45; 14: 182], а також прислівником [13: 292] і займенником [6: 118], їх треба переносити в наступний рядок. Бо не буде досягнуто результативності, яку в масовоінформаційній діяльності розглядають, зокрема, як спосіб дохідливості і засіб впливу [11: 189].

Виявляємо випадки, коли рядок газетного заголовка закінчується прийменником, сполучником і займенником. Наприклад:

\begin{tabular}{|c|c|}
\hline Неправильно & Правильно \\
\hline $\begin{array}{l}\text { Які хустки носили на } \\
\text { Волині сто років тому } \\
\text { (10 січня } 2019 \text { р.) }\end{array}$ & $\begin{array}{l}\text { Які хустки носили } \\
\text { на Волині } \\
\text { сто років тому }\end{array}$ \\
\hline $\begin{array}{l}\text { Вакцинація рятує від } \\
\text { смерті } \\
\text { (24 січня } 2019 \text { р.) }\end{array}$ & $\begin{array}{l}\text { Вакцинамія рятує } \\
\text { від смерті }\end{array}$ \\
\hline $\begin{array}{l}\text { Яке Різдво без } \\
\text { ковбаси і шинки? } \\
(27 \text { грудня } 2018 \text { р.) }\end{array}$ & $\begin{array}{l}\text { Яке Різдво } \\
\text { без ковбаси і шинки? }\end{array}$ \\
\hline $\begin{array}{l}\text { Пройти через пекло } i \\
\text { залишитися людиною } \\
\text { (31 січня } 2019 \text { р.) }\end{array}$ & $\begin{array}{l}\text { Пройти через пекло } \\
\text { i залишитися людиною }\end{array}$ \\
\hline
\end{tabular}




\begin{tabular}{|c|c|}
\hline Неправильно & Правильно \\
\hline $\begin{array}{l}\text { Волинські короваї } \\
\text { ділять в Італї та } \\
\text { Німеччині } \\
\text { (31 січня } 2019 \text { р.) }\end{array}$ & $\begin{array}{l}\text { Волинські короваї } \\
\text { ділять в Італії та Німеччині }\end{array}$ \\
\hline $\begin{array}{l}\text { Майстриня, яка } \\
\text { вишиває майбутнє } \\
\text { (13 грудня } 2018 \text { р.) }\end{array}$ & $\begin{array}{l}\text { Майстриня, } \\
\text { яка вишиває майбутнє }\end{array}$ \\
\hline $\begin{array}{l}\text { Украӥниі мають свій } \\
\text { фен-шуй - трипільський } \\
\text { (17 січня } 2019 \text { р.) }\end{array}$ & $\begin{array}{l}\text { Украӥниі мають свій фен-иуй- } \\
\text { трипільський }\end{array}$ \\
\hline
\end{tabular}

3. Важливу роль у творенні виразних заголовків відіграє заперечення, яке надає заголовкам полемічного характеру, оригінального та експресивного звучання. «Такі заголовки інтригують читачів, спонукають їх до неупередженого та критичного осмислення проблем» [2: 157].

Як зауважують дослідники, щоб не виникали труднощі у сприйнятті заголовка читачами, його рядки потрібно розташовувати так, щоб головний зміст був у полі ясної видимості [7: 47]. Коли ми переводимо зір з одного рядка на інший, то зосереджуємо увагу на змісті іншого рядка, не завжди помічаючи останні букви попереднього. Особливу увагу потрібно звертати на заперечення у газетних заголовках, зокрема, щоб частка «не» не була у кінці попереднього рядка заголовка [12]. Під час переведення погляду з одного рядка заголовка на наступний заперечна частка «не» може виявитися непоміченою, що спричинить помилкове сприйняття як заголовка, так і публікації в цілому. Наприклад:

\begin{tabular}{|c|c|}
\hline Неправильно & Правильно \\
\hline $\begin{array}{l}\text { Украӥнець не } \\
\text { пропустив жодного } \\
\text { уроку за } 11 \text { років } \\
\text { (6 січня } 2019 \text { р.) }\end{array}$ & $\begin{array}{l}\text { Українець не пропустив жодного уроку } \\
\text { за } 11 \text { років }\end{array}$ \\
\hline $\begin{array}{l}\text { Бард Володимир Козачук: } \\
\text { «Чотири роки не } \\
\text { співаю російською» } \\
\text { (6 січня } 2019 \text { р.) }\end{array}$ & $\begin{array}{l}\text { Бард Володимир Козачук: } \\
\text { «Чотири роки } \\
\text { не співаю російською» }\end{array}$ \\
\hline $\begin{array}{l}\text { Перевів гроші } \\
\text { мамі, щиоб не } \\
\text { конфіскували } \\
\text { (1 листопада } 2018 \text { р.) }\end{array}$ & $\begin{array}{l}\text { Перевів гроші мамі, } \\
\text { щоб не конфіскували }\end{array}$ \\
\hline
\end{tabular}

4. У заголовку не можна переносити власні імена (або ініціали й прізвища) [6: 118; 9: 45], бо порушується ясність читацького сприйняття [15: 5-6]. Як, наприклад, у такому заголовку:

\begin{tabular}{l|l}
\hline \multicolumn{1}{c|}{ Неправильно } & \multicolumn{1}{c}{ Правильно } \\
\hline $\begin{array}{l}\text { У пам'ять про боксера Василя } \\
\text { Лотоцького - міжнародний турнір } \\
\text { (6 січня 2019 р.) }\end{array}$ & $\begin{array}{l}\text { У пам'ять про боксера Василя Лотоиьького - } \\
\text { міжнародний турнір }\end{array}$ \\
\hline
\end{tabular}


Завдяки написанню власних імен (або ініціалів і прізвища) в одному рядку заголовок стає ціліснішим і змістовнішим.

5. У газетних заголовках часто наводять цифри. Адже «цифра - це не тільки знак для позначення кількості», а засіб яскравого факту, емоційного звучання, образного розкриття [5: 98-100]. Вибір цифрової форми написання зумовлений вимогою прискорити і покращити сприйняття, адже у цифровій формі число $є$ помітніше i схоплюється читачем набагато швидше, оскільки, «мабуть, не прочитується, не переводиться подумки у словесну форму, а саме схоплюється поглядом, що спрощує процес сприйняття тексту» [13: 62].

Варто звернути увагу на заголовок

За 100 км «Запорожещь»

брав шість літрів бензину

(1 листопада 2018 р.)

зважаючи на те, що, по-перше, числа подано у цифровій («100») і буквеній (прописом) формі («шість»), по-друге, одиниці вимірювання написано скорочено («км») i повністю («літрів»). На нашу думку, написання заголовка

За 100 км «Запорожецьв»

брав 6 л бензину

пришвидшило б і покращило б сприйняття чисел у тексті, зробило б його виразнішим.

Трапляються випадки, коли заголовки «страждають» від неправильного написання відмінкового закінчення порядкових числівників, що ускладнює читання. Наприклад:

$$
\begin{array}{ll}
\text { Украӥна - на } 88 \text { місиі у } & \text { Український } \\
\text { рейтингу якості життя } & \text { паспорт -на 28 } \\
\text { (4 жовтня 2018 р.) } & \text { місиі у світовому } \\
& \text { рейтингу } \\
& \text { безвізових країн } \\
& (13 \text { грудня 2018 p.) }
\end{array}
$$

Спочатку читач вимовляе подумки «вісімдесят вісім», «двадцять вісім», але, читаючи дальше «вісімдесят вісім місці», «двадцять вісім місці», змушений зупинитися і поправитися - перевести числівники у потрібний відмінок («на вісімдесят восьмому місці», «на двадцять восьмому місці»). Водночас таке написання підсвідомо запам'ятовується читачами.

Як зазначають дослідники, «відмінкове закінчення у порядкових числівниках, позначених арабськими цифрами, повинно бути однолітерним, якщо останній літері передує голосна, або дволітерним, якщо останній літері передує приголосна» [13: 66-67]. 3 огляду на це правильно так писати:

$$
\begin{array}{ll}
\text { Украйна -на 88-му місиі } & \text { Український паспорт - } \\
\text { у рейтингу якості життя } & \text { на 28-му місиі } \\
& \text { у світовому рейтингу } \\
& \text { безвізових країн }
\end{array}
$$

що покращить сприйняття чисел у заголовках газетних публікацій. 
6. Що робити у тих випадках, коли під час набору газетного заголовка обраним шрифтом «рядок не входить у форму»? Відповідь на це запитання дає В. Іванов: «Необхідно змінити кегль, накреслення чи навіть гарнітуру шрифту, аби тільки зберегти правильний змістовий розподіл на рядки» [6: 118].

Висновки. На підставі вищезазначеного та власного редакторського досвіду можемо підсумувати, що газетний заголовок повинен відповідати поліграфічним та видавничим нормам. Добираючи й опрацьовуючи заголовки, автори, редактори повинні усвідомлювати свою відповідальність за слово, звернене до читача. Якщо є сумнів, то заголовок треба прочитати двічі або й тричі, промовити вголос, щоб переконатись у його правильному написанні. Як радять дослідники, «ласкайте кожен заголовок доти, поки він не усміхнеться. Спочатку вам, а потім всім читачам» [3: 95].

Аналізуючи випадки неправильного розподілу газетного заголовка на рядки у виданні «Волинські новини», а також приклади подання цифр, наводили, на наш погляд, правильні відповідники, коли заголовки газетних публікацій були б більш виразними. Щоб це могли взяти до уваги під час літературного редагування і підготовки до друку наступних номерів видання. Бо, як писав I. Франко, «тільки висказання слабих сторін в однім ділі може поправити автора [у нашому випадку - літературного редактора, верстальника газети. - M. P.] на другий раз» [16].

Отже, форма заголовка як головного елемента газетного матеріалу не повинна шкодити його змісту, а, навпаки, робити його більш виразним і привабливим. Від цього значною мірою залежить вплив на читачів як заголовка, так і публікації в цілому.

\section{REFERENCES}

1. Алексеева, Н. Гаранина, К. Накорякова. Методика редактирования (техника правки, виды правки). Вып. 1. Москва: Изд-во Моск. ун-та, 1975. 88 с.

2. Баган М. Заперечення у заголовках сучасних ЗМІ. Культура слова. 2012. № 77. С. $153-157$.

3. Блисковский 3. Д. Название всегда важно. Москва, 1962. 96 с.

4. Гід журналіста. Київ: Ін-т масової інформації, 1999. 96 с.

5. Григораш Д. С. Теорія і практика редагування газети. Львів: Вид-во Львів. ун-ту, 1966. $168 \mathrm{c}$.

6. Іванов В. Ф. Техніка оформлення газети: навч. посіб. Київ: Знання, 2000. 222 с.

7. Іванченко Р. Г. Літературне редагування. 2-ге вид., доп. і перероб. Київ: Вид. обня «Вища школа», 1983. 248 с.

8. Кочан I. М. Лінгвістичний аналіз тексту: навч. посіб. 2-ге вид., перероб. і доп. Київ: Знання, 2008. 423 с.

9. Кулаков А. Н. Заголовок и его оформление в газете. Ленинград: Изд-во Ленинград. ун-та, 1982.88 с.

10. Лазарева Э. А. Заголовок в газете: учеб. пособие. Свердловск: Изд-во Урал. ун-та, 1989. $96 \mathrm{c}$.

11. Москаленко А. З. Теорія журналістики. Київ: Експрес-об'ява, 1998. 334 с.

12. Рипей М. В. Выразительность газетного заголовка. Медиа в современном мире. Молодые исследователи: материалы 14-й Междунар. конф. студентов, магистров и аспирантов (Санкт-Петербург, 11-13 марта 2015 г.) / под ред. М. А. Бережной; сост. А. Н. Марченко. Санкт-Петербург: С.-Петерб. гос. ун-т, 2015. С. 248-250. 
13. Справочная книга корректора и редактора / под. ред. А. Э. Мильчина. Москва: Книга, 1974. 416 с.

14. Феллер М. Д., Квітко І. С., Шевченко М. Г. Довідник коректора. Харків: Ред.-вид. відділ Книжкової палати УРСР, 1972. 408 с.

15. Феллер М. Д. Український університетський курс літературного редагування (задум автора-текст-сприймання читача). Наукові записки. Філол. науки. 2002. Т. 20. http://ekmair.ukma.edu.ua

16. Франко І. Лист до В. С. Давидяка. Зібрання творів: у 50 т. Київ: Наук. думка, 1986. T. 48. C. 8.

\title{
THE EXPRESSION OF THE NEWSPAPER HEADLINE
}

\author{
Mariia Ripei \\ Ivan Franko National University of Lviv \\ Generala Chuprynky Str., 49, 79044, Lviv, Ukraine \\ e-mail:maria-kr@ukr.net \\ https://orcid.org/0000-0001-6040-3539
}

The article traces the features of presenting newspaper's headline in terms of expression. Article's emotional affect mostly depends on its form of headline. It is especially important when the headline is rather long. When splitting a headine into different, one must remember to keep the main message in each of them.

The headline's line cannot end with a preposition or conjunction, as well as an adverb and pronoun; they should be transferred to the next line. The main message of the headline should be placed in the center of a line, so that readers don't have problems guessing what the article is about. When people read headlines they manage to focus on something specific, and tend to forget what they've read a couple of lines before.

Also it's important to never put the negative «no» part at the end of a line.

People's initials, surnames should be placed in one line, so that readers don't get confused. In order to make a headline easier to understand one can use the digital form of writing numbers.

A newspaper headline has to conform to the printing and publishing standards. The authors and editors (proofreaders) should be aware of their responsibility for the word addressed to the reader when they select and work up the headlines.

Headline's form as a main newspaper element is supposed to make the article more understandable and appealing. Because it also determines the impact both the headline and article have on readers.

Key words: newspaper headline, headline's line, form, semantic value. 